\title{
The Views of the Teacher Candidates on the Use of Kahoot as A Gaming Tool
}

\author{
https://doi.org/10.3991/ijet.v15i23.18811 \\ Huseyin Uzunboylu ${ }^{(\varpi)}$ \\ Member of Higher Education Planning, Accreditation and Coordination Board, \\ Nicosia, Turkey \\ huseyin.uzunboylulgmail.com \\ Elvira G. Galimova \\ Kazan Federal University, Kazan, Russia \\ Rashad A. Kurbanov, Asiya M. Belyalova \\ Institute of Legislation and Comparative Law under the Government \\ of the Russian Federation, Moscow, Russia \\ Nelia A. Deberdeeva \\ Plekhanov Russian University of Economics, Moscow, Russia \\ Mariia Timofeeva \\ First Moscow State Medical University, Moscow, Russia
}

\begin{abstract}
The process of integration of technology into education involves many tools and applications to be used in the classroom and outside teaching processes today. 'Kahoot' is one of such student response systems and one of the primary applications that can be utilised for the purposes such as gamification, formative assessment and peer learning procedures. Such applications are widely used for the purposes of bringing a gamification in the education industry nowadays. The primary purpose of this research is to determine the opinions of teachers who are active in the education industry and their experience in using 'Kahoot' as a teaching aid in bringing the diversification in the industry. In this study, a semi-structured interview form was used as a data collection tool. Opinions of prospective teachers participating in the study was taken into consideration to form an end conclusion of this research study. The research data also involves a semi-structured student opinion form, and a procedure of content analysis was undertaken in the analysis of the data. The study group of the research consists of 38 teacher candidates studying in Kazan (Volga region) Federal University, Institute of Legislation and Comparative Law under the Government of the Russian Federation, Plekhanov Russian University of Economics and Sechenov University. As a result of the study performed over the set of teachers and students, it was concluded that the 'Kahoot' program is widely beneficial for students and teachers. It was also concluded that the Kahoot program is helpful in eliminating the deficiencies in learning. However, one of the shortcomings of the 'Kahoot' program is that it is an internet-based programme. Hence it may be problematic for some of the students to use the
\end{abstract}


programme who have less knowledge in the internet domain. At the end of the study, a positive set of opinions about the Kahoot program was suggested, which majorly revolved around the idea that the programme is not internet based.

Keywords - Mobile learning; Teacher Candidates; KAHOOT; teaching processes, gamification

\section{Introduction}

Education and technology are the two essential elements that have significant roles in bringing a change in the overall transformation of human life. Education serves to reveal the innate powers and abilities of human beings and develops them to be stronger, more mature and creative human beings. Technology on the other hand helps human beings to utilise their knowledge and skills acquired through education on a better scale more efficiently and consciously. Learning continues throughout life. Researchers did a lot of research on different learning methods. Other learning methods help learning become continuous and permanent according to the knowledge and skills of individuals $[24,10,6,11,31]$.

New techniques and new methods are emerging every day in the field of education. Unlike teaching methodology used in the past, student-cantered approaches are effective in today's education arena. It is an inevitable fact to switch from the traditional method to alternative methods in mere fractions of time. The new methodology has brought transition from a 'teacher-centric' approach to a 'student-centric' approach $[18,8,2]$. With the developing technology, there have been significant differences between the tools and equipment used in the past and those used today. The needs of today's new generation students in the 21 st century is replaced from the old blackboard widely used; to the use of smartboards, projection devices, and portable computers. The changes and differences between the past and the present are from an educational approach in which knowledge is seen as an object transferred from teacher to student; it progressed towards an educational approach in which students construct knowledge altogether under the guidance of the teacher [21,13]. The students are bored with the old native technologies and are more willing to use the newer technologies, that makes them more skilled and the learning, interesting [19].

The expression 'digitally native' is used for the newer generations [19]. Digital literacy is defined as the ability to access and reveal information through digital tools. To be digitally literate, individuals need to fulfil high-level critical thinking skills such as research, inquiry, problem solving, and decision making [35,32]. Since the new generation, which is digitally advanced, spends their days with digital tools such as computer, mobile phones, music players, video games etc. It is claimed that equipping through the learning environments with technological tools, conducting activities and projects appropriate to students motivate their 'technological literacy levels' and contribute to students' success at schools and motivates them further $[27,16,5]$. 
Technological advances expanded the boundaries of knowledge and differentiated perspectives. Technology have started to be used in education widely [25,33,34]. The technical dimension aims to create a 'computer and media literacy' that allows students and instructors to use online learning without technical glitches. The social goal in this era is to create a sphere where technology is brought in collaboration with students' network where the students are willing to share their experiences with peers and/or the teachers in a positive way hence motivating and even inspiring them to achieve together an emotional, social, and cognitive commitment [29]. Computeraided education, which has also been used in the education of individuals in the need of special education, has produced positive results $[26,22,14,13]$.

With the rapid development of science and technology, 'educational technology' has emerged to a lot of extent. Developments in educational technology has brought a development in the digital environment. There are many digital tools, settings and applications that can be used today for this purpose. One of them is 'Kahoot'. It is a free online gamification environment that can be used to test students and their content knowledge. 'Kahoot' is a game-based learning platform used to review students' knowledge and offers them to take a break from the traditional classroom way of attaining knowledge. This platform is one of the most popular game-based learning platforms, with over 70 million unique active monthly users [17]. \ It is also possible to use Kahoot with hardware such as smartphones, laptops, tablet computers, and desktop computers. Developing technologies have also changed the learning styles of digital natives and their expectations from teachers and learning environment [1]. For digital immigrants to create a suitable learning environment for digital natives, they must be able to use the same language as them. Digital games, which are encountered in many areas in today's social spheres, can also be widely used in attaining lessons to attract digital natives [30]. In this context, educational game and gamification concepts can be considered as essential tools to increase the interest of digital natives in process of learning \& teaching.

The most popular education technology used today is the 'Kahoot' program. The opinions of the teacher-candidates about the Kahoot program are critical in their professional lives. This is important in terms of determining the competencies, knowledge, positive and negative aspects of the program.

\subsection{Purpose of the research}

This research aims to determine the opinions of teacher-candidates about 'Kahoot' application, which is one of the primal technological advancements done in today's era in the field of education.

For the same purpose, the following questions were sought:

- What are your opinions about the 'Kahoot' application? (positive and negative aspects)?

- What are the advantages and disadvantages of using 'Kahoot' for the teacher?

- Do you plan to use 'Kahoot' or similar 'Kahoot' applications in your future lessons? 


\section{Methodology Adapted}

The research is descriptive and was conducted with the interview method, which is one of the qualitative research methods. Hennink, Hutter, and Bailey [12] stated that the focus of qualitative research in a research model helps us understand the participants. Qualitative research involves their perspective on a situation or a topic, and their comments on the topic.

\subsection{Research group}

A case study approach constituted the methodological framework of this study. This study was conducted with 38 senior (4th grade) students of the faculty of education in the fall semester of 2019-2020. The requirement of teacher candidates to take "instructional technology and material design course" was taken as basis. Among the preservice teachers who knew about the 'Kahoot, application' were included in this study. The data of this study were collected with open-ended questions developed by the researcher to determine whether the students would use new technological programs in their professional lives in the future, whether they find the 'Kahoot' program useful, and whether they have any deficiencies. When asked if they use their smartphones, all prospective teachers (38 in number) answered the question in a 'Yes' which made us conclude that smartphones are being widely used by individuals nowadays. Likewise, when the teachers were asked whether they use tablets or not, it was concluded that 25 of such teachers used tablets whereas 13 of the teachers did not.

The demographic information of the teacher-candidates participating in the study is given in Table 1.

Table 1. Demographic information of the instructors

\begin{tabular}{|l|l|c|}
\hline & \multicolumn{1}{|c|}{ Description } & N \\
\hline \multirow{4}{*}{ Gender } & Female & 21 \\
\cline { 2 - 3 } & Male & 17 \\
\cline { 2 - 3 } & Total & 38 \\
\hline \multirow{5}{*}{ Department } & Pre-school teaching department & 10 \\
\cline { 2 - 3 } & Classroom teaching department & 10 \\
\cline { 2 - 3 } & Science teaching department & 9 \\
\cline { 2 - 3 } & Department of mathematics teaching & 9 \\
\cline { 2 - 3 } & Total & 38 \\
\hline
\end{tabular}

\subsection{Data collection tools}

A semi-structured questionnaire consisting of demographic information developed by the researchers and open-ended questions were used as a data collection tools in this study, which helped in determining the opinions of preservice teachers on the 'Kahoot' application. The open-ended questions in the questionnaire were created using the literature and the researchers' own experiences. The questionnaire was first examined by three experts (1 linguist, two computer teachers) experienced in qualita- 
tive research, and necessary corrections were made according to their feedback. In this case, the questionnaire form for the pilot application was applied to 5 trainers outside the study group and the comprehensibility of the questions was checked.

\section{$3 \quad$ Results}

\subsection{What are your opinions about the Kahoot application? (positive and negative aspects)}

Table 2. Teacher /c andidates opinions about the Kahoot application

\begin{tabular}{|l|c|}
\hline \multicolumn{1}{|c|}{ POSITIVE } & N \\
\hline \multicolumn{1}{|c|}{$\boldsymbol{N E G A T I V E}$} & 10 \\
\hline Effective learning & 9 \\
\hline Providing fun repetition & 9 \\
\hline Technology supported education & 8 \\
\hline The competition is comprehensive & \\
\hline \multicolumn{1}{|c|}{$\boldsymbol{|}$} & 18 \\
\hline Internet is required & 10 \\
\hline Leaving the usernames to the student & \\
\hline
\end{tabular}

The prospective teachers, who were studying in the last year, were asked about the positive and negative aspects of the 'Kahoot' program. Opinions on this question positively stated that it provides effective learning (10'), offers fun repetition (9), technology-supported education (9), and encourages students to learn due to its comprehensive competition (8). Their responses to the negative aspects of the 'Kahoot' program were collected under two headings. It was stated as the negative aspect that the Kahoot program did not work in case of not having internet (18). Likewise, leaving the Kahoot program's user account name to the student (10) may pose a problem. Creating a user with the same name or adding unethical names to user names may cause problems in the course.

Examples of the opinions of the teacher candidates:

"Teachers aim to ensure that any information must be learned. We use techniques to ensure permanent learning. By creating an effective learning environment, 'Kahoot' actively involves students in learning their lessons."

"Kahoot application is the most used educational and technological game tools. Its difference from other technological tools is that it allows repetition and shows deficiencies. It provides learning by creating a competitive environment."

"The Kahoot program is a very effective and enjoyable application program. But its only disadvantage is that it doesn't work without the internet connection. Students may not always have the internet." 
3.2 What are the advantages and disadvantages of using Kahoot for the teacher?

Table 3. Advantages and disadvantages of using Kahoot for the teacher

\begin{tabular}{|l|c|l|c|}
\hline & $\mathbf{N}$ & & $\mathbf{N}$ \\
\hline ADVANTAGES & 38 & Seeing the shortcomings & 15 \\
\hline & & Increase student motivation & 10 \\
\hline & & Facilitating teaching & 8 \\
\hline & & High level student-student-teacher interaction & 6 \\
\hline & & Very easy to use & 2 \\
\hline DISADVANTAGES & 1 & Maintaining class control & 1 \\
\hline
\end{tabular}

The teacher candidates were asked about the advantages and disadvantages of the Kahoot application for them. When responding, thirty-eight of the teachers talked in length about the advantages, while only one teacher talked about the disadvantage.

As a preservice teacher, the advantages of the Kahoot program is to see the shortcomings of the students (15), to increase the motivation of students to participate in the lesson (10), to facilitate the teaching (8), to provide a high level of studentstudent-teacher interaction (6), and that the program is easy to use (2). have been reached.

Examples of the opinions of the teacher candidates:

"Techniques that are far from traditional methods interests the students towards the learning of the lesson. The 'Kahoot' application is delightful and interesting. The best part of the 'Kahoot' application is that it allows us to see whether the subjects we teach are actually learned and what were deficiencies that occurred in the process."

"Learning made via the 'Kahoot application' allow bored students to return to the lectures by attracting the attention of the distracted students and increasing their motivation."

"When using the 'Kahoot' application, it may not be an easy task to control the volume in the classroom or to control the students.

\subsection{Do you plan to use 'Kahoot' or similar 'Kahoot' applications in your future lessons?}

When asked whether the future teachers would use the Kahoot program in their profession, thirty teachers answered in 'YES'. However, eight teachers' candidates stated that they would not use the program. They noted that the reason for not using the program is that the 'Kahoot' program is internet-based. When asked whether the future teachers would use the Kahoot program in their profession, they thirty-five of them answered in 'YES'. The preservice teachers responded that they use other gamification training programs Plickers (5), Classcraft (3), \& Khan Academy (1). 


\section{Discussion and Conclusion}

The prospective teachers, who were teaching in the last year, were asked about the positive and negative aspects of the 'Kahoot' program. Opinions were positively stated that it provides effective learning (TEN), offers fun repetition (NINE), technologysupported education (NINE), and encourages students to learn due to its comprehensive competition (EIGHT). It was concluded that the teacher candidates had favourable opinions about the 'Kahoot' program. Licorish, Owen, Daniel \& George [15] examined the studies on the 'Kahoot' program in their literature review.

Their responses to the negative aspects of the 'Kahoot' program were collected under two headings. The negative part stated that the 'Kahoot' program does not work if you don't have internet (EIGHTEEN). Likewise, leaving the 'Kahoot' program's user account names to be chosen by the students themselves may pose a problem (TEN). Creating a user with the same name or adding unethical names to user names may cause problems. In this case, the 'Kahoot' program can be developed to solve the internet problem. In this way, the internet problem will be eliminated.

The preservice teachers were asked about the advantages and disadvantages of the 'Kahoot' application for them. Thirty-eight of the preservice teachers put forward its benefits, while one preservice teacher indicated its disadvantages. The pre-service teachers stated that they have nothing to say as a disadvantage. The preservice teachers found the 'Kahoot' program, one of the WEB 2.0 tools, is compelling. They saw benefits for students as well as for the teachers.

As a preservice teacher, the advantage of the Kahoot program is to see the shortcomings of the students (15), to increase the motivation of students to participate in the lesson (10), to facilitate the teaching (8), to provide a high level of studentstudent-teacher interaction (6), and that the program is easy to use (2). Teachers aim to teach their lessons correctly. With the applications made in the 'Kahoot' program, they can see the shortcomings of the students and can repeat them the incomprehensible issues. 'Kahoot', with ninety-six students at 'Purdue University' in the United States of America was used for seven weeks. It was found that the experimental group performed significantly better in the final exam (79.56 for the experimental group, 56.83 for the control group) [3]. It showed a $12 \%$ higher test result for students playing 'Kahoot'! as compared to those subjected to the traditional teaching methods [4]. A case study with 324 university students from Portugal demonstrated this with 'Kahoot'. The average grade increased by $6.4 \%$ compared to traditional teaching, improved the levels of weaker students by $12 \%$ and failed less than the course [9].

In a similar study, the use of technology also increases the importance of educational games. The study course aims to examine the effect of educational games on the academic achievements, motivations, and attitudes of primary school students. The participants of the study consisted of 90 students studying at a public primary school in the 2017-2018 academic year. The research is also essential in a way that it is done with primary school students who are younger individuals, who lacked in the literature. In the study designed in a quasi-experimental model, an experimental procedure was performed with two different units ("In the Class" and "Numbers") in the English course, and it was observed that the usage of educational games increased the 
interest of students. On the other hand, while educational games caused a difference in motivation towards learning the English lessons, no difference was observed in attitudes of the students in learning the traditional way [20].

When asked whether future teachers would use the 'Kahoot' program in their profession, all (35) answered yes. The preservice teachers responded that they would use the gamification training programs Plickers (5), Classcraft (3) and Khan Academy (1). This situation is very gratifying. It can be concluded that knowledge of new technological tools used in teaching and positive attitudes towards these technologies will make future teacher candidates adapt to newer technologies and make learning more enjoyable, permanent, and fun. It is very pleasing that teachers know about such technological tools and think about using them in their profession. To increase their knowledge of other technical tools, the number of educational technologies courses they take during their university education can be improved. It can be given in different years. Thus, the new generation of teachers will adapt to the new generation of students and provide training.

\section{Acknowledgements}

1. The work was performed according to the Russian Government Program of Competitive Growth of Kazan Federal University.

2. The work was performed according to the project of improving competitiveness of the leading Russian universities among the leading world scientific education centres "5-100" of First Moscow State Medical University.

\section{References}

[1] Arabacı, I. B., \& Polat, M. (2013). Dijital Yerliler, Dijital Göçmenler Ve Sınıf Yönetimi. Elektronik Sosyal Bilimler Dergisi, 12(47): 11-20. https://dergipark.org.tr/tr/ pub/esosder/issue/6161/82824 https://doi.org/10.17823/gusb.2531

[2] Batıbay, E. F. (2019). Web 2.0 Uygulamalarinin Türkçe Dersinde Motivasyona Ve Başariya Etkisi: Kahoot Örneği (Master's thesis, Eğitim Bilimleri Enstitüsü). https://doi.org/10. 16916/aded.616756

[3] Bawa, P. (2019). Using kahoot to inspire. Journal of Educational Technology Systems, 47(3), 373-390. https://doi.org/10.1177/0047239518804173

[4] Boboc, A. L., Orzan, G., Stoica, I., \& Niculescu-Ciocan, C. (2018). Gamification and Game-Based Learning-a Solution for Romanian Education System? eLearning \& Software for Education, 1. DOI: 10.1016/j.sbspro.2014.07.679

[5] Conole, G., \& Alevizou, P. (2010). A literature review of the use of Web 2.0 tools in Higher Education. A report commissioned by the Higher Education Academy.

[6] Devedzic, V., \& Devedzic, M. (2019). Technology-Enhanced Assessment at universities and in schools: An initiative. International Journal of Learning and Teaching, 11(3): 89-98. https://doi.org/10.18844/ijlt.v11i3.4319

[7] Elmas, R., \& Geban, Ö. (2012). 21. Yüzyıl Öğretmenleri için Web 2.0 Araçları.International Online Journal of Educational Sciences, 4(1). 
[8] Elmas, R., Demirdöğen, B. ve Geban, Ö. (2011). Pre-service chemistry teachers' images about science teaching in their future classrooms. Hacettepe University Journal of Education, 40: 164-175.

[9] Esteves, M., Pereira, A., Veiga, N., Vasco, R., \& Veiga, A. (2017, September). The use of new learning technologies in higher education classroom: A case study. In International Conference on Interactive Collaborative Learning (pp. 499-506). Springer, Cham. https:// doi.org/10.3991/ijep.v8i2.8146

[10] Fanzeres, L. J. L. T., \& Cruz-Santos, A. (2018). Adulthood transition of students with special educational needs in Portugal: Preliminary results of professional's perceptions. Global Journal of Psychology Research: New Trends and Issues, 8(1): 44-51. https://doi.org/10. 18844/gjpr.v8i1.3272

[11] Hamdan, S., Isik, B., \& Jallad, S. (2019). Impact of creativity in nursing education. New Trends and Issues Proceedings onAdvances in Pure and Applied Sciences, (11): 39-45. https://doi.org/10.18844/gipaas.v0i11.4312

[12] Hennink, M., Hutter, I., \& Bailey, A. (2020). Qualitative research methods. SAGE Publications Limited.

[13] Keser, Ö. F. (2005). Recommendations towards developing educational standards to improve science education in Turkey. The Turkish Online Journal of Educational Technology, 4(1), 46-53.

[14] Landicho, J. A. (2016). Voisee Communicator: An android mobile application for hearingimpaired and blind communications. International Journal of Interactive Mobile Technologies (iJIM), 10(4), 26-31. https://doi.org/10.3991/ijim.v10i4.5859

[15] Licorish, S. A., Owen, H. E., Daniel, B. \& George, J. L. (2018). Students' perception of Kahoot!'s influence on teaching and learning. Research and Practice in Technology Enhanced Learning, 13(9): 1-23. https://doi.org/10.1186/s41039-018-0078-8

[16] Bicen, H., \& Kocakoyun, S. (2018). Perceptions of students for gamification approach: Kahoot as a case study. International Journal of Emerging Technologies in Learning (iJET), 13(02): 72-93. https://doi.org/10.3991/ijet.v13i02.7467

[17] Lunden, I. (2018). E ducation quiz app Kahoot says it's now used by $50 \%$ of all US K-12 students, 70M users overall, Vol. 2019, TechCrunch

[18] Polat, M. (2019). Yükseköğretimde Kahoot Kullanmak Ya Da Kullanmamak: Öğretmen Adaylarının Kahoot'la Öğretime Yönelik Görüşleri. Ulusal Eğitim Akademisi Dergisi, 3(2), 139-157. https://doi.org/10.32960/uead.587469

[19] Prensky, M. (2001). Digital natives, digital immigrants. On the Horizon, 9(5), 1-6

[20] Sabirli, Z., \& Coklar, A. (2020). The effect of educational digital games on education, motivation and attitudes of elementary school students against course access. World Journal on Educational Technology: Current Issues, 12(3): 165-178. https://doi.org/10.18844/wjet. v12i3.4993

[21] Salama, R., Uzunboylu, H., \& El Muti, M. (2020). Implementing online questionnaires and surveys by using mobile applications. New Trends and Issues Proceedings on Humanities and Social Sciences, 7(3), 48-70. https://doi.org/10.18844/prosoc.v7i2.5016

[22] Demirok, M. S., Gunduz, N., Yergazina, A. A., Maydangalieva, Z. A., \& Ryazanova, E. L. (2019). Determining the Opinions of Special Education Teachers Regarding the Use of Assistive Technologies for Overcoming Reading Difficulties. International Journal of Emerging Technologies in Learning (iJET), 14(22), 141-153. https://doi.org/10.3991/ijet. v14i22.11761

[23] Sancar, I., Tozkoparan, S., \& Odabasi, H. (2017). Use of mobile technologies in special education: A content analysis. Journal of Education and Special Education Technology, 3(1), 1-12. https://doi.org/10.18844/jeset.v3i1.3890 
[24] Tenekeci, F., \& Uzunboylu, H. (2020). Determining the relationship between the attitudes of private teaching institution teachers towards lifelong learning and their competence. International Journal of Learning and Teaching, 12(1), 1-16. https://doi.org/10.18844/ijlt.v12 $\underline{\mathrm{i} 1.4559}$

[25] Murdiono, M., Suyato, S., Rahmawati, E.L. \& Aziz, M.A. (2020). Developing an AndroidBased Mobile Application for Civic Education Learning. International Journal of Interactive Mobile Technologies (iJIM), 14(16): 180.193. https://doi.org/10.3991/ijim.v14i16.149 $\underline{67}$

[26] Uzunboylu, H., Bicen, H., \& Cavus, N. (2011). The efficient virtual learning environment: A case study of web 2.0 tools and Windows live spaces. Computers \& Education, 56(3), 720-726. https://doi.org/10.1016/j.compedu.2010.10.014

[27] Uzunboylu, H., Ozcinar, Z., Kolotushkin, S., Kalugina, O., \& Zulfugarzade, T. (2019). Research and Trends in Technology and Gifted Child: Results of a Content Analysis. International Journal of Emerging Technologies in Learning (iJET), 14(22), 56-69. https://doi.org/ $\underline{10.3991 / \text { ijet.v14i22.11751 }}$

[28] Wang, A. I., \& Tahir, R. (2020). The effect of using Kahoot! for learning-A literature review. Computers \& Education, 149: 103818. https://doi.org/10.1016/j.compedu.2020.1038 $\underline{18}$

[29] Yehya, F. (2020). Promoting Technology- Implementation Learning paradigm for online learning in secondary education. Global Journal of Information Technology: Emerging Technologies, 10(1): 12-21. https://doi.org/10.18844/gjit.v10i1.4620

[30] Yıldırım, İ., \& Demir, S. (2014). Gamification and education Oyunlaştırma ve eğitim. Journal of Human Sciences, 11(1): 655-670.

[31] Yıldız, E., \& Uzunboylu, H. (2018). Comparıson Of Instructional Design Models: An Instructional Design Model; Example of The Near East University. International Journal of Innovative Research in Education, 5(3): 74-84. https://doi.org/10.18844/ijire.v5i3.3835

[32] Yildiz, E. (2020). Opinions of academicians on digital literacy: A phenomenology study. Cypriot Journal of Educational Sciences, 15(3): 469 - 478. https://doi.org/10.18844/cjes. v15i3.4913

[33] Yildiz, E. P., Çengel, M., \& Alkan, A. (2019). Social Media Attitudes among Vocational School Students. International Journal of Evaluation and Research in Education, 8(3), 384391. https://doi.org/10.11591/ijere.v8i3.20248

[34] Baglama, B., Haksiz, M., \& Uzunboylu, H. (2018). Technologies used in education of hearing-impaired individuals. International Journal of Emerging Technologies in Learning (iJET), 13(09): 53-63. https://doi.org/10.3991/ijim.v14i16.14967

[35] Duran, E., \& Özen, N. E. (2018). Türkçe derslerinde dijital okuryazarlık. Türkiye Eğitim Dergisi, 3(2): 31-46.

\section{Authors}

Huseyin Uzunboylu graduated from Anadolu University, completing a degree in BSc Educational Communicating and Planning in 1991. He graduated from Ankara University; completed a degree in MA Curriculum and Instruction in 1995 and completed PhD in area of Educational Technology in 2002. He became Assistant Professor in 2013, Associate Professor in 2015 and Professor of Educational Technology in 2010 at Cyprus Near East University. He is a member of Higher Edu- 
cation Planning, Supervision, Accreditation and Coordination Board, Nicosia, North Cyprus, Turkey. Email id: huseyin.uzunboylu@gmail.com

Elvira G. Galimova is $\mathrm{PhD}$ in Education, Associate Professor of the Department of Pedagogy of Higher Education, also she is the Head of Scientific and Methodical Department of the Institute of Psychology and Education at Kazan (Volga region) Federal University (18 Kremlyovskaya Street, 420000, Kazan, Russia). Her research interests for the last decade have been connected with students' project activity and as well as problems of teacher education. She has more than 70 published articles in Russian and foreign journals. E-mail: elyagalimowa@yandex.ru

Rashad A. Kurbanov is a Doctor in Law, Professor of the Department of Legal Basis of the Economic Activity at the Institute of Legislation and Comparative Law under the Government of the Russian Federation (34 Cheryomushkinskaya Street, 117218, Moscow, Russia). He is well known in Russia with his scientific works dedicated to the different problems of government, legislation and comparative law. He is also interested on the problems concerning the methodology of scientific works. Email: mos-ssp@mail.ru

Asiya M. Belyalova is a Head of International Cooperation Department at the Institute of Legislation and Comparative Law under the Government of the Russian Federation (34 Cheryomushkinskaya Street, 117218, Moscow, Russia). She has more than 80 published scientific works in Russia and other countries dedicated to different problems of law methodology. E-mail: asyulya@mail.ru

Nelia A. Deberdeeva is a Senior Lecturer of the Department of Psychology, Plekhanov Russian University of Economics (36 Stremyannyi Pereulok, 115093, Moscow, Russia). Her main scientific and professional interests are related to the implementation of modern active and innovative methods of teaching and upbringing, education. E-mail: debnelya@yandex.ru

Mariia Timofeeva is a Senior Lecturer of Human Anatomy Department at the First Moscow State Medical University (Sechenov University) (2 bld.4 Bolshaya Pirogovskaya Street, 119435, Moscow, Russia). Her main scientific and professional interests are related to teaching, research and development of psychological and pedagogical methods and technologies for organizing the educational process, the development of innovative principles and systems in teaching. E-mail: timmaria@mail.ru

Article submitted 2020-09-14. Resubmitted 2020-10-05. Final acceptance 2020-10-05. Final version published as submitted by the authors. 